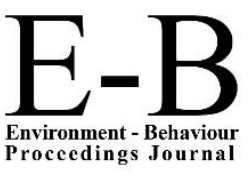

\title{
AicE-Bs2015Barcelona
}

$6^{\text {th }}$ Asia-Pacific International Conference on Environment-Behaviour Studies,

Barcelona School of Architecture (ETSAB), Barcelona, Spain,31 Aug.- 05 Sep. 2015

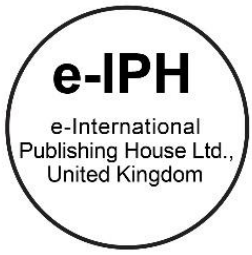

\section{Attitude and Perception of Young Audience towards Patriotism in Independence Day TV Commercials}

\author{
Fazlina Jaafar ${ }^{\star}$, Azian Mohd Zain 1 , Mohd Syuhaidi Abu Bakar² \\ 1 Graphic Department, Faculty Of Art \& Design, \\ ${ }^{2}$ Creative Writing Department, Faculty Of Film, Theatre \& Animation, \\ University Teknologi MARA, Shah Alam, Malaysia.
}

\begin{abstract}
Quantitatively, this study intends to identify the attitude and perception of young audiences in Malaysia towards Independence day TV commercials from Petronas, and Maxis Berhad in celebrating the Independence Day. Firstly, respondents were exposed to three TV commercials with the same theme and purpose - to represent the spirit of patriotism. Later, these respondents were given a set of questionnaire to be filled. Data were collected using Purposive Sampling and analyzed with statistical analysis (SPSS) using Descriptive analysis represented by using the value of percentages, $X$, and SD. Findings of this study revealed that respondents have negative attitudes towards independence day, but positive attitudes towards the patriotism showed in all TV commercials. They also showed positive perception on independence day television commercials, as high number of respondents have agreed that the concept, theme and art direction of television commercial about love and live in unity without racism will be the style of benchmark for the future style of direction towards producing television commercial for Independence Day and are considered vital to instill patriotism towards the nation.
\end{abstract}

C 2016. The Authors. Published for AMER ABRA by e-International Publishing House, Ltd., UK. Peer-review under responsibility of AMER (Association of Malaysian Environment-Behaviour Researchers), ABRA (Association of Behavioural Researchers on Asians) and cE-Bs (Centre for Environment-Behaviour Studies, Faculty of Architecture, Planning \& Surveying, Universiti Teknologi MARA, Malaysia.

Keywords: Attitude; Perception; Patriotism; TV Commercials

\section{Introduction}

Merdeka, it's a word that define the meaning of the most memorable date by all Malaysians. What does Merdeka Day mean to Malaysians? To ordinary Malaysians, it is a time to reflect and pay tribute to the sacrifices made by the past leaders to achieve independence. Every year, on the 31st August, Malaysians regardless of their race, religion and political stand will once again come together to celebrate the country's Independence Day, or known as Merdeka Day. On this significant day, Malaysians show the world their true colours means that Malaysians are virtually colour-blind because no matter what is their skin colour, they live in peace and harmony together - always tolerant and have mutual respect (Tourism Malaysia, 2014).Patriotism defined as the feeling of love or devotion to one's country. Being patriotic also requires a feeling of wanting what is best for the nation and doing things that would make the nation proud. Patriotism also implies feelings of solidarity and mutual responsibility among

\footnotetext{
${ }^{*}$ Corresponding author. Tel.: +0-000-000-0000

E-mail address: fuzz.jaafar75@gmail.com
}

(C) 2016. The Authors. Published for AMER ABRA by e-International Publishing House, Ltd., UK. Peer-review under responsibility of AMER (Association of Malaysian Environment-Behaviour Researchers), ABRA (Association of Behavioural Researchers on Asians) and cE-Bs (Centre for EnvironmentBehaviour Studies, Faculty of Architecture, Planning \& Surveying, Universiti Teknologi MARA, Malaysia. 
people of different ethnicities and religious backgrounds. A multiracial and multi-religious nation like Malaysia needs to find commonalities due to the differences that exist among the various groups. Therefore, through the spirit of patriotism and love for the nation, these differences can be transcended, thus allowing a strong basis for a consensus among the citizens. A patriotic spirit was instilled in the hearts and minds of all citizens. Serious efforts need to be taken to nurture the spirit of patriotism especially among youths today. Although patriotism is an innate feeling, it is the responsibility of various parties to help spur a love for the country. Ultimately, true Malaysians would always want the country to remain peaceful and harmonious. Real Malaysians would ensure that the bond among fellow citizens remains strong and intact (Enizahura, 2012).

Chand (2015), stated that television often used as the medium of communication because of the reach it delivers. Television advertising also makes a strong visual and emotional impact. The interaction of sight, sound, colour, motion and drama creates a stronger emotional response than most other forms of advertising media. The advantages offered by television advertising are:

- The creative potential for the fusion of sight, sound and motion through pictures, symbols, movement, colour, text, music, effect and dialogue ensures advertising has a high impact on viewers.

- It gives access to vast audiences, and can raise awareness very quickly

- It gives opportunities to match advertising messages to likely audiences for programmes.

- It appeals to the sense.

- It is very convenient and effective to demonstrate through the television.

- High attention is possible due to the combination of sound and visuals.

- It is a very powerful media in building up the image of the product, service and public service announcement.

According to Steve Edward, Associate Professor of Advertising, Southern Methodist University, advertising has tremendous power to shape our attitude about our world and ourselves. It also inform people of important ideas, and change behavior (Moriarty, Mitchell \& Wells, 2012). Moriarty, Mitchell \& Wells, 2012 also highlighted that advertising and other forms of marketing communication are first of all a form of communication, messages that are designed to have some impact. In a sense, effective advertising is a message to a consumer that gets attention and provides information. Advertising campaigns of all types are present in our everyday life and the concern for how the advertising campaigns messages affect adult behavior (Elena (Dragan), 2012). Advertising has always been interested in looking for the idea and finding that simple but unique concept that determines more and more people to buy and appreciate the promoted trademark (Amalancei, 2012). Various study has been conducted to test TV commercials, such Totu (2010), AnuarZaini, Lim, Low and Harun (2005) and Karupaiah et al. (2008) tested it on youth's lifestyles and identities, paying special attention to consumer attitudes, desires and habits. But very little was done to test TV commercials in the aspect of patriotism. Thus, this study intends to use three TV commercial on patriotism and test it on some purposive sample respondents. This research focused on the attitude and perception of a young adult towards patriotism in local TV commercials. Quantitatively, this study intends to identify the attitude and perception of young audiences in Malaysia, towards Independence day TV commercials from Petronas, and Maxis Berhad.

\section{Methodology}

This study employs the quantitative approach content research, which includes analysis of survey questionnaires and application demo as a research instrument. The populations of the study are Art and Design students from Universiti Teknologi MARA. Respondents consists of 50 students from the Graphic Department, Faculty of Art \& Design, Universiti Teknologi MARA were selected as a sample (respondents). According to Roscoe (1975) sample sizes of larger than 30 and less than 500 are appropriate for most research. The reason behind this is that, these students are with the potential of becoming future designers and art directors, thus by identifying their level of attitude on independence day and perception on independence day television commercials, the faculty might be able to gauge any negativity towards both variables (if any) in the earliest stage of the undergraduate studies. Firstly, respondents were exposed with three commercials with the same theme and purpose - to represent the spirit of independence. Later, these respondents were given a set of questionnaire to be filled. Data were collected using Purposive Sampling and were analyzed with statistical analysis (SPSS) using Descriptive analysis represented by using the value of $X$ and SD. $X$ represents the mean (also known as average) scores of the result. SD represents the standard deviation gives an idea of how close the entire set of data is to the average value. The research instrument in this study comprises of 3 sections, namely demographics, user's attitude, and user's perception. All sections except for Section 1 used 5 points Likert Scale ranging from 1 = "Strongly Disagree" to 5 = "Strongly Agree". Results were categorized in descriptive statistics 
(percentages) for section 1 and $X$ and SD for the rest of the sections. Crosschecking with the subject matter Professors to get the standardization of the questionnaire and wording of the questions was done to get the instrument's validity.

\section{Findings and Discussions}

\subsection{Respondents' Characteristics}

The demographic characteristics of respondents indicated that $58.3 \%$ of the respondents were male with $72 \%$ of them spent 6-7 hours per day in online activities.

\subsection{User's Attitude Towards Independence Day}

The first objective of this study is to identify the attitude and perception of a young adult towards Independence Day television commercials. For the attitude towards patriotism is found that the respondents disagreed on why must we as Malaysian celebrates it very year $(x=1.0, s d=0)$. Respondents also disagree on the celebration such as watching the parade $(x=1.18$, $s d=0.388)$. The respondents somehow disagreed with raising the national flag on vehicles, balcony and even along the street $(x=1.14, s d=0.351)$. Respondents also are unaware every year there are a specific theme for Independence Day $(x=1.14$, $s d=0.351)$. Most of the respondent disagreed that Malaysia is safe $(x=1.30, s d=0.463)$. They also disagreed that Malaysia is stable on economy and politics $(x=1.44, s d=0.501)$. The respondents disagreed that television commercial with the patriotic theme had the positive effect towards them $(x=1.12, s d=0.328)$. The respondents disagreed that they needed a high spirit of patriotism as they were the next generation that would determine the sovereignty of Malaysia $(x=1.22, s d=0.418)$. These findings are not consistent with the result of the attitude to encourage the patriotism spirit among young adults as they were the next generation that would determine the sovereignty of Malaysia.

\subsection{Users Perception on Independence Day television commercials}

The second objective of this study is to determine the perception of concept and theme of each commercial that can be the benchmark of the next style of concept. The theme and art direction when producing the Independence Day television commercials. Three commercials, which identified as instrument: TVC A, TVC B, and TVC C have used for this study. They were selected based on the different approaches of concept, theme, and story line from different corporate companies for their corporate social responsibility.

For the first television commercial, which identify as TVC A, was first showed to the respondents. The concept and theme for this commercial were the journey of two boys towards the transition period from 1950's to 2000's, and the journey ends on 2014. The respondents understand the message behind this television commercial $(x=3.34, s d=0.479)$. They also agreed that the television commercial is entertaining $(x=3.34, s d=0.479)$. They agreed that TVC A gives the meaning of independent $(x=3.34$, $s d=0.519)$. The respondents agree that concept of this commercial increase their spirit of patriotism $(x=3.32, s d=0.513)$. The respondents agree that the concept of TVC A can influence the next generation to determine the independence of Malaysia $(x=3.24, s d=0.591)$. Respondents agreed that the next generation will relate to the message in TVC $A(x=3.26, s d=0.565)$. Respondents regarded on TVC A style will be the benchmark for the future style of direction towards producing a television commercial for Independence Day ( $x=3.36$, sd=0.525).

For the second television commercial, which identify as TVC B, were later showed to the respondents. The concept and theme for this commercial were all Malaysians were all families which possessing such great unity and harmony among the people of all races, cultures and religions. The respondents understand the message behind this television commercial $(x=3.60$, $s d=0.535)$. They also agreed that the television commercial is entertaining $(x=3.64, s d=0.485)$. They agreed that TVC $B$ gives the meaning of independent $(x=3.26, s d=0.723)$. The respondents agree that concept of this commercial increase their spirit of patriotism $(x=3.24, s d=0.591)$. The respondents agree that the concept of TVC $B$ can influence the next generation to determine the independence of Malaysia $(x=3.36 \mathrm{sd}=0.663)$. Respondents agreed that the next generation will relate to the message in TVC $B(x=3.40, s d=0.606)$. Respondents regarded on TVC $B$ style will be the benchmark for the future style of direction towards producing a television commercial for Independence Day $(x=3.26, s d=0.633)$. 
For the third television commercial, which identify as TVC C, were the last TVC showed to the respondents. The concept and theme for this commercial were about the children of our future were color blind. They don't practice racism in their daily lives, and we should remain that all races are same as long as we live in peace and harmony. The respondents understand the message behind this television commercial $(x=3.70, s d=0.463)$. They also agreed that the television commercial is entertaining $(x=3.74, s d=0.443)$. They agreed that TVC $C$ gives the meaning of independent $(x=3.52, s d=0.580)$. The respondents agree that concept of this commercial increase their spirit of patriotism $(x=3.48, s d=0.580)$. The respondents agree that the concept of TVC $C$ can influence the next generation to determine the independence of Malaysia $(x=3.58, s d=0.499)$. Respondents agreed that the next generation will relate to the message in TVC C $(x=3.64, s d=0.525)$. Respondents regarded on TVC $C$ style will be the benchmark for the future style of direction towards producing a television commercial for Independence Day ( $x=3.64$, sd=0.525).

These findings shows that between these three commercials, TVC $C$ has shown that their concept, theme and art direction style will be the benchmark for future style of direction towards producing television commercial for Independence Day ( $x=3.64$, $\mathrm{sd}=0.525)$. The frequencies also show that TVC $\mathrm{C}$ statistic results on strongly agree were $66 \%$ compared to TVC B total percentage $36 \%$, and TVC A with total percentage was $38 \%$.

\section{Conclusion}

Respondents of this study showed negative attitudes towards independence day, but positive attitudes towards the patriotism showed in all TV commercials. They also showed positive perception on independence day television commercials, as the high number of respondents have agreed that the concept. The theme and art direction of television commercial about love and live in unity without racism will be the style of benchmark for the future style of direction towards producing television commercial for Independence Day and are considered vital to increase patriotism towards the country. Considered as young adult of Malaysian's generation, these respondents are clearly identifying themselves with the most locally authentic and important part of their lives, such as their childhoods, memories, families, traditions, religion and culture.

\section{Acknowledgements}

We would like to express the deepest appreciation to Universiti Teknologi MARA who have always supported, encouraged and believed in our interest towards research writing.

\section{References}

(n.d.). Retrieved July 1, 2015, from The Wonders Of Malaysia's Independence Day Celebration from http://corporate.tourism.gov.my/images/media/features/007\%20Merdeka\%20Day.pdf

Abdul Aziz, E. (n.d.). True Malaysians and Patriotism. Retrieved 2015, from http://www.ikim.gov.my/index.php/en/the-star/8539-true-malaysians-and-patriotism

AnuarZaini, M. Z., Lim, C. T., Low, W. Y., \&Harun, F. (2005). Factors affecting nutritional status of Malaysian primary school children.Asia Pacific Journal of Public Health, 17(2), 71-80.

Brindusa-Mariana A. Retrieved June 30, 2015. From New Trends in Brand Strategies. World Congress of Administrative \& Political Sciences (ADPOL-2012), Procedia - Social and Behavioral Sciences, Volume 81, 28 June 2013, Pages 275-279

Declaration of Independence of Malaya. (2015, June 25). Retrieved July 1, 2015, from http://www.arkib.gov.my/en/web/guest/pengisytiharankemerdekaan-tanah-melayu

Engaging Users Using Movie Mobile Advertising: Technology ... (n.d.). Retrieved from http://www.researchgate.net/profile/Mohd_Syuhaidi_Abu_Bakar/publication/27134117

Hari Malaysia is unity in diversity | theSundaily. (n.d.). Retrieved from http://www.thesundaily.my/news/1171555

Karupaiah, T., Chinna, K., Loi, H. M., Lim, S. M., \& Noor, M. I. (2008). What's on Malaysian television? A survey on food advertising targeting children.Asia Pacific Journal of Clinical Nutrition, 17(3), 483-491.

Popescu, E (Dragan), Retrieved June 30, 2015. From A case study on the influence of public advertising campaigns in child education. 5th International Conference EDU-WORLD 2012 - Education Facing Contemporary World Issues, Procedia - Social and Behavioral Sciences, Volume 76, 15 April 2013, Pages 686-689

Roscoe, J.T. (1975). Fundamental Research Statistics for the Behavioral Sciences, New York: Holt, Rinehart and Winston.

S Chand, S. (n.d.). Retrieved July 1, 2015, from http://www.yourarticlelibrary.com/advertising/television-advertising-advantages-and-limitations/22439/

S. Moriarty, N. Mitchell, W. Wells, (2012). Advertising \& IMC: Principles and Practice, Ninth Edition. 
S. Olenski. (2012). What Makes A TV Commercial Memorable And Effective? http://www.forbes.com/sites/marketshare/2012/10/19/what-makes-a-tvcommercial-memorable-and-effective/

Television Advertising: Advantages and Limitations. (n.d.). Retrieved from http://www.yourarticlelibrary.com/advertising/television-advertising-advantages-

Top TV Advertising in India. (n.d.). Retrieved from http://genxadds.com/

Totu, A. (2010). Consumerism in Malaysia: Mass Media, Lifestyles and Identities. Kota Kinabalu: PenerbitUniversiti Malaysia Sabah.

True Malaysians and Patriotism - Official Portal Institue of ... (n.d.). Retrieved from http://www.ikim.gov.my/index.php/en/the-star/8539-true-malaysians-andpatriotism

Why is social responsibility important to a business? (n.d.). Retrieved July 1, 2015, from http://www.investopedia.com/ask/answers/041015/why-socialresponsibility-important-business.asp 